Canadian Science Publishing

Canadian Journal of Earth Sciences Revue canadienne des sciences de la Terre

\title{
Late Ordovician jaw-bearing polychaetes from Anticosti Island, eastern Canada, and their biogeographic significance
}

\begin{tabular}{|r|l|}
\hline Journal: & Canadian Journal of Earth Sciences \\
\hline Manuscript ID & cjes-2015-0222.R1 \\
\hline Manuscript Type: & Article \\
\hline Date Submitted by the Author: & 20-Jan-2016 \\
\hline Complete List of Authors: & $\begin{array}{l}\text { Hints, Olle; Tallinn University of Technology, Institute of Geology } \\
\text { Tonarová, Petra; Czech Geological Survey } \\
\text { Desrochers, André; University of Ottawa, Department of Earth Sciences }\end{array}$ \\
\hline & scolecodonts, jawed polychaetes, Ordovician, Anticosti, paleobiogeography \\
\hline
\end{tabular}

SCHOLARONE ${ }^{m}$

Manuscripts 


\section{Late Ordovician jaw-bearing polychaetes from Anticosti}

\section{Island, eastern Canada, and their biogeographic significance}

4 Olle Hints ${ }^{1}$, Petra Tonarová ${ }^{2}$ and André Desrochers ${ }^{3}$

$6{ }^{1}$ Institute of Geology, Tallinn University of Technology, Ehitajate tee 5, 19086 Tallinn, Estonia;

7 olle.hints@ttu.ee

$8 \quad{ }^{2}$ Czech Geological Survey, Geologická 6, 15200 Prague 5, Czech Republic;

9 petra.tonarova@geology.cz

$10{ }^{3}$ Department of Earth and Environmental Sciences, University of Ottawa, ON, Canada K1N

11 6N5; adesro@uottawa.ca

12

13 Corresponding author: Olle Hints, Institute of Geology, Tallinn University of Technology,

14 Ehitajate tee 5, 19086 Tallinn, Estonia; olle.hints@ttu.ee, +372 5130157. 


\section{Abstract}

18 The Upper Ordovician to Lower Silurian shallow marine succession of Anticosti Island, eastern

19 Canada, provides one of the most complete records across the Hirnantian in the world. This study

20 reports a diverse assemblage of scolecodonts (polychaete jaws) from the upper Katian and

21 Hirnantian Vauréal, Ellis Bay and basal Becscie formations of western Anticosti. The collection

22 of ten samples includes ca. 30 species representing 10 families. The fauna is dominated by

23 polychaetaspids, mochtyellids, paulinitids and polychaeturids. The family Xanioprionidae and

24 genera Pistoprion, Tetraprion and Rakvereprion are documented for the first time from the

25 Ordovician of Laurentia. The Anticosti polychaete fauna shows great similarity to the

26 contemporaneous faunas of Baltoscandia. This is evidenced by a high relative abundance of

27 mochtyellids and polychaeturids and a number of common species, thus suggesting that the

28 closing Iapetus Ocean at that time did not constitute a barrier for the dispersal of jaw bearing

29 polychaetes. Some Laurentian influence is, however, indicated by the occurrence of

30 hadoprionids. Distinct Katian Vauréal and Hirnantian Ellis Bay scolecodonts are likely reflecting

31 faunal reorganization linked to local environmental changes rather than the initial phase of the

32 Hirnantian mass extinction.

34 Key words: scolecodonts, jawed polychaetes, Ordovician, Anticosti, paleobiogeography. 


\section{Introduction}

38 The richly fossiliferous Upper Ordovician to Lower Silurian succession of Anticosti Island,

39 eastern Canada, is long known as one of the most complete records spanning the Ordovician-

40 Silurian in the world. It contains key sections to document and decipher the environmental and

41 biotic changes of the Hirnantian glaciation and mass extinction (Copper 2001; Delabroye et al.

42 2011a; Copper et al. 2013; Copper and Jin 2014; Ghienne et al. 2014). The Anticosti strata have

43 been studied for various groups of shelly fossils, stratigraphy and sedimentology since the early

44 20th century (Schuchert and Twenhofel 1910). Data on microfossils started to emerge somewhat

45 later, with recent years giving a number of contributions on chitinozoans (Achab et al. 2013),

46 acritarchs and cryptospores (Vecoli et al. 2011; Delabroye et al. 2011a). The scolecodonts

47 (polychaete jaws), common organic-walled microfossils in Paleozoic rocks, have remained

48 virtually unknown from Anticosti, apart from few notes (Bertrand and Héroux 1987; Petryk

49 1987) and a single systematic paper (Courtinat and Racheboeuf 1997). In the latter study, a small

50 collection from the Upper Ordovician Vauréal Formation was described using the obsolete

51 single-element-based classification (as opposed to natural multi-element-based taxonomy; see

52 Eriksson et al., 2000 for review). In spite of its limited scope, the study (Courtinat and

53 Racheboeuf 1997) suggests that the Anticosti succession should yield diverse well preserved

54 scolecodont assemblages.

55 Several recent papers have described Late Ordovician polychaete faunas of Baltoscandia (Hints

56 2000; Hints and Eriksson 2007, 2010; Eriksson and Hints 2009; Hints et al. 2010; Eriksson and

57 Frisk 2011), Laurentian mid-continent (Eriksson and Bergman 1998, 2003; Eriksson et al. 2005),

58 and Gondwanan areas (Hints et al. 2015). These studies have helped to shed new light on the

59 paleobiogeographical patterns as well as biodiversification history of early Paleozoic jaw-bearing 
60 polychaetes (Hints and Eriksson 2007; Eriksson et al. 2013). They also highlighted gaps in the

61 data currently available. Moreover, the ongoing studies on polychaete faunas across the end

62 Ordovician mass extinction in Baltoscandia and elsewhere (by OH and PT) stress the need to

63 initiate similar work in other key regions, using appropriate methods and multi-element-based

64 taxonomy. This approach should allow a better understanding of distribution patterns and

65 increase the usefulness of scolecodonts in stratigraphy, paleogeography and environmental

66 interpretations.

67 For the present study, we analyzed a set of relatively small samples from the upper Vauréal, Ellis

68 Bay and basal Becscie formations, spanning the late Katian and Hirnantian interval. Our aims are

69 to: (1) document the taxonomic composition of the fauna and contribute to the understanding of

70 paleobiogeographical patterns of jawed polychaetes, (2) reveal any temporal changes in

71 polychaete communities in link with the Hirnantian mass extinction; (3) assess most suitable

72 habitats for jawed polychaete faunas, and (4) spot the best lithologies and stratigraphic levels for

73 scolecodont studies.

75 Geological settings and stratigraphy

76 During the Late Ordovician, Anticosti Island was on the eastern margin of Laurentia and located

$7720-30^{\circ}$ southern paleolatitudes (Torsvik and Cocks 2013). The Upper Ordovician to Lower

78 Silurian succession exposed on the island consists mostly of sediments formed on a carbonate

79 ramp in a shallow epeiric sea (Sami and Desrochers 1992). Facies changes across the island are

80 distinct: the central and western sections consist of offshore storm-dominated carbonate facies,

81 whereas the eastern sections are made up of mixed storm-dominated siliciclastic-carbonate facies 
82 typical of a proximal shore environment (Desrochers et al. 2010). The succession did not record

83 the major Taconian compression present in the nearby Appalachians, thus the Anticosti strata are

84 thermally and tectonically unaltered (Bertrand and Héroux 1987; Bordet et al. 2010).

85 The original stratigraphic framework (Schuchert and Twenhofel 1910; Twenhofel 1928), was

86 recently modified and enhanced (Desrochers et al. 2010, Copper et al. 2013, Copper and Jin 2014

87 and references therein). The Upper Ordovician to Lower Silurian succession of the western

88 Anticosti is represented by the upper Vauréal, Ellis Bay and basal Becscie formations.

89 Subdividing these formations into members have recently been resolved at the regional scale

90 (Achab et al. 2013). We follow here the usage of Desrochers et al. (2010) and Copper et al.

91 (2013). An ongoing debate is the correlation of the Ellis Bay Formation with other sections,

92 particularly in Baltoscandia (Delabroye and Vecoli 2010). Several studies have recently proposed

93 that the entire $\sim 90 \mathrm{~m}$ thick Ellis Bay Formation in western Anticosti is of Hirnantian age

94 (Desrochers et al. 2010; Achab et al. 2011, 2013; Copper et al. 2013; Melchin et al. 2013; Copper

95 and Jin 2014; Ghienne et al. 2014). On the other hand, a contrasting interpretation based largely

96 on chemostratigraphic data suggests that only the upper part of the Ellis Bay Formation, the

97 topmost Lousy Cove and Laframboise members, correspond to the Hirnantian Stage (Kaljo et al.

98 2008; Jones et al. 2011; Bergström et al. 2014, 2015). In either case, the sampled interval of the

99 present study corresponds to the latest Katian and Hirnantian (the topmost sample analyzed lying

100 below the base of the Silurian (Desrochers et al. 2010; Achab et al. 2013). 


\section{Materials and methods}

103 For the present study, ten samples were collected by AD from the Anse aux Fraises to Pointe

104 Laframboise in the western part of Anticosti Island (Fig. 1). A comprehensive lithological

105 description of these localities is available in Desrochers et al. (2010).

106 The samples, 80-270 $\mathrm{g}$ in weight, were dissolved in ca. 7\% acetic acid. The insoluble residues

107 were gently washed through 45 micron sieve and microfossils were hand-picked from water by a

108 glass pipette to be stored in glycerin. Selected specimens were imaged using a Zeiss Evo MA15

109 scanning electron microscope. The abundance of each taxon was derived from the count of the

110 most abundant diagnostic elements in the sample (usually either left or right posterior maxilla,

111 but others have used the count of all posterior maxillae giving a ca. 1.5 times larger number). The

112 descriptive terminology and naming of apparatus elements follow Kielan-Jaworowska (1966).

113 The specimens are deposited at the Institute of Geology, Tallinn University of Technology, under 114 a collection number GIT 714.

\section{Results}

\section{Abundance, diversity and taxonomic composition}

118 All but one samples from the Laframboise Member in the uppermost Ellis Bay Formation, were

119 productive for scolecodonts. The maximum abundance reached nearly 800 specimens per $\mathrm{kg}$

120 (Fig. 2; corresponding to ca. 1300 posterior maxillae per kg), being comparable with latest

121 Ordovician samples of Baltoscandia (Hints et al. 2010). The entire collection contains 304

122 posterior maxillae that are diagnostic at least to the genus level. Taking into account the simple 
123 teeth and fragmented specimens, the overall number of scolecodonts extracted was about 500.

124 The preservation of the material is good to excellent with numerous three-dimensional jaws, but

125 fractured and pyritized specimens are also present. A few partial jaw apparatuses were found. At

126 present, the collection is not large enough to confidently reconstruct the jaw apparatuses of all

127 species and assess their range of morphological variability. Thus several forms discussed below

128 and shown on Fig. 3 are referred to using an open nomenclature.

129 The entire collection contains nearly 30 species representing 16 genera and 10 families (Fig. 2).

130 In the richest sample, 13 species are recorded, which is less than productive Katian to

131 Rhuddanian samples of Baltoscandia. This difference is largely attributable to relatively small

132 sample size of the Anticosti samples. Only three Anticosti samples are sufficiently large to

133 discuss the scolecodont diversity and assemblage structure. The latest Ordovician polychaete

134 faunas of Anticosti are mainly composed of polychaetaspids, mochtyellids and paulinitids. This is

135 characteristic of Ordovician and Silurian assemblages worldwide (Hints and Eriksson 2007;

136 Eriksson et al. 2013). In two Anticosti samples, polychaeturids and xaniprionids are also

137 common, but all other families are representing a minor portion of the scolecodont assemblage.

138 Taxa with placognath and ctenognath type jaw apparatuses (mochtyellids, xanioprionids,

139 tetraptionids) are relatively abundant, reaching up to $20 \%$ in the Vauréal Formation and $35 \%$ in

140 the Ellis Bay Formation. This contrasts with previously reported Late Ordovician polychaete

141 faunas of Laurentia, where ctenognath-placognath taxa are less abundant (Hints and Eriksson

142 2007). In contemporaneous Baltic faunas however, ctenognath-placognath taxa account for

143 nearly 50\% of specimens (Eriksson and Hints 2009). 


\section{Remarks on selected taxa}

146 Mochtyellidae. In Anticosti samples, the mochtyellids are represented by at least four genera:

147 Mochtyella, Pistoprion, Vistulella, and Rakvereprion. Additionally a few specimens belonging to

148 the enigmatic Lunoprionella and to a similar yet undescribed genus, have been recorded. All

149 these genera are also common in Baltoscandia. The genus Mochtyella is represented by at least

150 five different species: $M$. cf. trapezoidea (Fig. 3C), M. cf. duplicidentata (Fig. 3D), M. cf cristata,

$151 M$. ex gr. polonica and M. ex gr. fragilis. Additionally several mochtyellid jaws are assigned to

152 Mochtyella spp. as the left compound maxillae often lack good diagnostic features.

153 Stratigraphically M. cf. trapezoidea is restricted to the Vauréal Formation, whereas other species

154 are common in the Ellis Bay Formation. This pattern shows local ranges likely related to different

155 environmental preferences, possibly transition from warm-water to cool-water conditions.

156 Pistoprion transitans (Fig. 3G, H) occurs through the Ellis Bay and basal Becscie formations,

157 occasionally accounting for ca. $30 \%$ of the assemblage. The present find is the first record of

158 intercontinental distribution of this species. Another, yet undescribed, species of Pistoprion is

159 restricted to the Silurian and has previously been documented from different regions including

160 Baltica, Canadian arctic and Perunica (Hints and Eriksson 2007; Tonarová et al. 2012, 2014). P.

161 transitans is common in the Baltic Upper Ordovician strata (Hints 1998, 2000; Eriksson and

162 Hints 2009) and spans into the lower Silurian. It may be one of predominating taxa in both latest

163 Katian as well as Hirnantian strata, with maximum relative abundance over $70 \%$ recorded in the

164 Kuldiga Formation (Hints et al. 2010). Notably, Pistoprion is regarded to be an environmentally

165 sensitive genus restricted to relatively shallow shelf settings (Hints 2000), which may limit its

166 occurrence in Anticosti. Vistulella cf. kozlowskii (Fig. 3E, F) occurs sporadically through the

167 Vauréal and Ellis Bay formations. It is another long-ranging taxon common in Baltica and 
168 elsewhere. In addition to the above-mentioned genera the collection contains a single specimen of

169 Rakvereprion cf. balticus, which is one of predominating taxa in Baltoscandian deeper shelf

170 settings during the Katian Pirgu Regional Stage (Hints 2000, 2001).

171 Xanioprionidae. The family is represented by a single species, Xanioprion sp. A (Fig. 3I, J),

172 characterized by differentiated MI and MII elements of sub-symmetrical placognath type jaw

173 apparatus. It occurs in two samples of the Ellis Bay Formation, providing the first confident

174 identification of the family Xanioprionidae in Laurentia. In the Baltic region very similar forms

175 are recorded through the Upper Ordovician and lower Silurian strata (Hints 1998, 2000).

176 Tetraprionidae. Tetraprion cf. pozaryskae (Fig. 3A) was recovered from sample 410 in the Ellis

177 Bay Formation. A similar and likely conspecific taxon is common in the Sandbian and Katian of

178 Baltoscandia (Hints 1998), but has so far not been recorded from other regions. Another, yet

179 undescribed species of tetraprionids (Tetraprionidae gen. et sp. nov., Fig. 3B) is more common on

180 Anticosti, occurring in both Vauréal and Ellis Bay formations. The same species may be

181 abundant in the Hirnantian strata of Baltoscandia (Hints 2001; Hints et al. 2010). Its full

182 stratigraphic range is, however, extending from the Katian to at least the early Wenlock

183 (Szaniawski 1970; Rubel et al. 2007). A similar taxon has been documented previously from the

184 Late Ordovician of Laurentia (Eriksson and Bergman 2003) and Ludlow of Perunica (Tonarová

185 et al. 2012).

186 Polychaetaspidae. The family is represented by at least five species assigned to the genus

187 Oenonites (=Polychaetaspis according to Szaniawski and Drygant 2014) in the Anticosti

188 samples. Most samples contain isolated jaws belonging to this genus, but lacking distinct

189 features; these are referred to as Oenonites spp. (example on Fig. 3O). In the Ellis Bay Formation 
190 two species of the genus are determined, the rare Oenonites sp. B and Oenonites aff.

191 wyszogrodensis (Fig. 3K, L, Q). The latter taxon belongs to a group of very similar species that

192 occur through Ordovician and Silurian strata worldwide. In the Vauréal Formation

193 polychaetaspids are represented by at least three species. Maxillae of Oenonites sp. A, and a

194 single jaw of Oenonites cf. marlenediesae (Fig. 3P) were recovered from sample 268. The latter

195 species closely matches the material described from the type Cincinnatian region (Eriksson and

196 Bergman 2003), but the full identification requires the left MI and basal plate to be found.

197 Oenonites aff. latus (Fig. 3M, N) occurs abundantly in sample 268. This species differs from the

198 typical Baltic O. latus in having much longer shank on right MI and overall smaller size. Similar 199 specimens have been previously documented from the Pirgu Regional Stage (upper Katian) of

200 Baltoscandia (cf. Hints, 2000, pl. 1:21).

201 Polychaeturidae. Pteropelta gladiata (Fig. 3R-U) occurs most abundantly (up to 30\% of

202 scolecodonts) in the Vauréal Formation, but also spans through the Ellis Bay Formation. Previous

203 records of polychaeturids from Laurentia are rare, limited to few specimens of $P$. gladiata from

204 the upper Richmondian of Ohio (Hints and Eriksson 2010). This family occurs on other

205 paleocontinents, but is thought to be one of the most characteristic features of the Baltic faunal

206 province during the Ordovician (Hints and Eriksson 2010; Eriksson et al. 2013). This suggests a

207 relatively close faunal link between Anticosti and Baltica. The Anticosti specimens are

208 morphologically identical with those occurring in the Pirgu Regional Stage of Baltoscandia,

209 where $P$. gladiata sometimes accounts for more than $20 \%$ of specimens in nearshore settings.

210 Polychaeturids are, however rare in the Porkuni Regional Stage as well as in the Silurian in

211 Baltoscandia (Hints and Eriksson 2010). 
212 Ramphoprionidae. This family is most common in the Vauréal Formation, where Ramphoprion

213 cf. ineptus (sensu Eriksson and Bergman 2003) (Fig. 3V, W, Y) reaches over 12\% of specimens

214 in sample 268. This taxon was reported from the Cincinnatian region (Eriksson and Bergman

215 2003), but closely related taxa also occur in the Late Ordovician of Baltoscandia. In some

216 samples, ramphoprionid jaws are present, but not in sufficient number for complete apparatus

217 reconstructions, thus they are referred to as Ramphoprion sp. (Fig. 3X). A relatively high

218 percentage of ramphoprionids is generally characteristic of Laurentian and Gondwanan rather

219 than Baltic assemblages (Hints et al. 2015).

220 Paulinitidae. A single paulinitid genus Kettnerites (see the taxonomic discussion by Szaniawski

221 and Drygant 2014) is present in the Ellis Bay and basal Becscie formations. In sample 318, it

222 accounts for nearly $40 \%$ of specimens. Its absence in the Vauréal Formation is probably either

223 due to our small sample size or unfavorable environment, as paulinitid jaws have been collected

224 from the Vauréal Formation below the currently sampled interval (Courtinat and Racheboeuf

225 1997). Paulinitids are a typical component of Ordovician faunas in Laurentia and Gondwana. In

226 Baltica, they are rare until the Hirnantian and become abundant only in the Silurian (Eriksson et

227 al. 2013). At the species level, the identification of paulinitid jaws is difficult. Based on the most

228 diagnostic second maxillae (Bergman 1989), the Anticosti collection seems to hold two separate

229 species. Kettnerites sp. A (Fig. 3Z-AD) in the Ellis Bay Formation is characterized by single

230 cusp on the left MII and double cusp with intermediate denticle on the right MII. A different

231 species occurs in the Becscie Formation. Neither of these species seems to match the

232 stratigraphically closest Laurentian species $K$. invisibilis revised by Bergman (1991), $K$.

233 sylvanensis described by Eriksson et al. (2005), or the paulinitids collected from the Ordovician-

234 Silurian boundary interval of Baltoscandia (OH and PT unpublished data). 
235 Hadoprionidae. This monotypic family is represented in the Anticosti collection by Hadoprion

236 cervicornis (Fig. 3AH, AI), a conspicuous and easy-to-identify taxon occurring in sample 318

237 from the Ellis Bay Formation. H. cervicornis was first described from the Cincinnatian of

238 Toronto (Hinde 1879), and later thoroughly revised and discussed based on large collections from

239 the Cincinnati region (Eriksson and Bergman 1998, 2003). The same species has been recently

240 recorded from the Silurian (but not Ordovician) of Baltoscandia. Thus, Eriksson et al. (2013)

241 considered hadoprionids as rare, but typical element of Laurentian polychaete faunas of the

242 Ordovician Period.

243 Kalloprionidae and Atraktoprionidae. These families are represented by only a few specimens

244 attributed to the geographically and stratigraphically widespread genera Kalloprion (Fig. 3AE),

245 Leptoprion and Atraktoprion (Fig. 3AF, AG). Additional material is necessary for comparison.

\section{Discussion and conclusions}

\section{$248 \quad$ Paleobiogeographic affinities}

249 Katian polychaete faunas are well known from Baltoscandia (Hints 2000; Eriksson and Hints

250 2009; Hints and Eriksson 2010), the type Cincinnatian area of Laurentia (Eriksson and Bergman

251 2003; Eriksson et al. 2005) and to some extent Gondwana (Hints et al. 2015). The latter authors

252 studying scolecodonts from the Arabian Peninsula proposed that Gondwanan and Laurentian

253 polychaete faunas were more similar to each other than to Baltica, based on high proportion of

254 paulinitids, ramphoprionids and polychaetaspids, and relative scarcity of placognath forms in

255 both regions. The late Katian polychaete fauna from Anticosti, however, shows Baltic rather than 
256 mid-continent Laurentian affinity. In particular, this is suggested by a number of common species

257 and high abundance of polychaeturids and mochtyellids (Fig. 4) that is considered characteristic

258 of Baltic Late Ordovician faunas (Hints and Eriksson 2007; Eriksson et al. 2013). Still,

259 Laurentian elements are also present in the Vauréal assemblage, notably Oenonites cf.

260 marlenediesae and the occurrence of paulitinids as reported by Courtinat and Racheboeuf

261 (1997).

262 The Hirnantian scolecodonts are less known globally, with the main collections coming from

263 Baltoscandia (Hints 1999, 2001, Hints et al. 2010; OH and PT unpublished data), complemented

264 by a brief report from South Africa, Gondwana (Whittle et al. 2008). The Anticosti jawed

265 polychaete assemblage from the Ellis Bay Formation is strikingly similar to the fauna described

266 from the Kuldiga Formation of Estonia and Latvia (Hints 2001; Hints et al. 2010). This is

267 especially apparent at the genus- or family-level assemblage structure (Fig. 4), in addition to a

268 number of common species, most importantly Pistoprion transitans. The fact that several Baltic

269 taxa typical of, or restricted to the Hirnantian have not been identified in the Anticosti samples

270 may be explained by the small size of the collection. Alternatively this may be due to restricted

271 biogeographic distribution of these taxa or misinterpreted correlations. The Laurentian influence

272 on the Ellis Bay assemblage is suggested by the occurrence of Hadoprion cervicornis, unknown

273 from the Hirnantian of Baltoscandia, and possibly from the higher proportion of paulinitids.

274 The similarity between the Anticosti and Baltoscandia polychaete faunas may either reflect a

275 close biogeographic link between the two basins or a globally distributed Hirnantian polychaete

276 fauna, much like the Hirnantia Fauna; this remains to be tested. New data from other continents

277 is vital to resolve this question. The closing of the Iapetus Ocean, however, did not constitute a

278 barrier for the dispersal of jaw bearing polychaete worms since relatively similar faunas were 
279 present on both sides of that ocean (e.g Laurentia and Baltica) during the latest Ordovician. A

280 close biogeographic link between Anticosti and Baltoscandian Basin has also been documented

281 for acrtitarchs and cryptospores (Delabroye et al. 2011b; Vecoli et al. 2011).

\section{Stratigraphic distribution}

284 Comparison between the scolecodont assemblages of the Vauréal and Ellis Bay formations shows

285 some differences (Fig. 2); for instance, the occurrence of Oenonites aff. latus and Mochtyella cf.

286 trapezoidea in the former, and the appearance of Kettnerites sp. A and Pistoprion transitans in

287 the latter formation. It is well documented that near this boundary about two thirds of coral,

288 stromatoporoid and brachiopod genera gradually disappear, which is interpreted as the first pulse

289 of the Hirnantian mass extinction event on Anticosti (Copper et al. 2013). Microphytoplankton

290 (acritarchs) show a step-wise turnover in the upper Vauréal and lower Ellis Bay formations, with

291 few taxa becoming extinct, but many forms making their first appearance (Delabroye et al.

292 2011a).

293 Previous data on latest Ordovician and earliest Silurian scolecodonts show that few, if any,

294 polychaete genera become extinct during the Hirnantian (Eriksson et al. 2013). Some species that

295 contribute to the local turnover pattern on Anticosti succession are known to be long-ranging

296 elsewhere. An example is Pistoprion transitans that spans from the Sandbian to Llandovery in

297 Baltoscandia (Hints 2001; Hints et al. 2010). The changes between Vauréal and Ellis Bay

298 scolecodonts may largely reflect assemblage reorganization linked to local environmental

299 changes rather than extinction. With further sampling, some species (e.g., Kettnerites sp. A, 
300 Oenonites aff. latus) should be tested whether they mark stratigraphic or environmental events 301 on Anticosti.

302 The scolecodonts reported in this study provide no conclusive evidence to add to the debate on

303 Anticosti-Baltoscandia correlation issues (Delabroye and Vecoli 2010). Overall the Ellis Bay

304 assemblage is very similar to that of the Porkuni Regional Stage (Kuldiga Formation), only

305 Tetraprion cf. pozaryskae would suggest Pirgu rather than Porkuni age.

\section{Paleoenvironmental notes}

308 The late Katian (Pirguan) scolecodonts from Estonia (Hints 2000) show a clear differentiation of

309 polychaete faunas along the paleobasin gradient, with the richest assemblages present in the

310 shallowest-water settings. Several long-ranging species were also identified as potential

311 environmental indicators. The Anticosti assemblages in both Vauréal and Ellis Bay formations

312 represent the typical shallow-shelf assemblage characterized by a relatively high diversity and

313 abundance, and by the occurrence of environmentally sensitive species such as Pteropelta

314 gladiata and Pistoprion transitans. The comparable Baltoscandian faunas are documented in the

315 Adila Formation (Katian) of northern and central Estonia, and in the Kuldiga Formation

316 (Hirnantian) of southern Estonia and Latvia, where shallow-water environments shifted during

317 the Hirnantian sea-level drawdown. This environmental similarity is corroborated with other

318 elements of the studied Anticosti microfossil assemblage; for instance, the occurrence of

319 Blastammina-type foraminiferans and relatively low abundance of chitinozoans in the richest

320 scolecodont samples. 


\section{Future study prospects}

323 Scolecodont samples were too small in number and in size to allow a full taxonomic or

324 quantitative study of the Anticosti polychaete faunas. Our study, however, documents good to

325 excellent preservation, high abundance and diversity of scolecodonts in the Upper Ordovician

326 strata, suggesting a clear potential for a thorough work in the future. Based on the scolecodont

327 yield of our samples, we estimate that $0.5-1 \mathrm{~kg}$ samples should be used to recover most species

328 and sufficient number of specimens for apparatus reconstructions. The most interesting

329 stratigraphic intervals are the Vauréal-Ellis Bay boundary beds up to sample 318, the topmost

330 part of the Lousy Cove Member, and the basal Silurian strata of the Becscie Formation. This

331 should provide further insights into the paleobiogeographic distribution and extinction patterns of

332 jaw-bearing polychaetes globally and add to the stratigraphic and paleoenvironmental usefulness

333 of scolecodonts.

\section{Acknowledgements}

336 The authors are grateful to the reviewers Prof. Jisuo Jin and Prof. Hubert Szaniawski for their

337 helpful suggestions that have improved the manuscript. The research was supported by the

338 Estonian Research Council (PUT611 and ETF9039 to OH), the Natural Sciences and Engineering

339 Council of Canada Discovery grant (2015-06668 to AD) and Czech Science Foundation (GJ15-

$34013525 \mathrm{Y}$ to PT). It is a contribution to the IGCP project 591. 


\section{References}

343 Achab, A., Asselin, E., Desrochers, A., Riva, J.F., and Farley, C. 2011. Chitinozoan

344 biostratigraphy of a new Upper Ordovician stratigraphic framework for Anticosti Island,

345 Canada. Geological Society of America Bulletin, 123(1-2): 186-205. doi:10.1130/B30131.1.

346 Achab, A., Asselin, E., Desrochers, A., and Riva, J.F. 2013. The end-Ordovician chitinozoan

347 zones of Anticosti Island, Québec: Definition and stratigraphic position. Review of

348 Palaeobotany and Palynology, 198: 92-109. doi:10.1016/j.revpalbo.2012.07.019.

349 Bergman, C.F. 1989. Silurian paulinitid polychaetes from Gotland. Fossils and Strata, 25: 1-127.

350 Bergman, C.F. 1991. Revision of some Silurian Paulinitid scolecodonts from western New York.

$351 \quad$ Journal of Paleontology, 65: 248-254.

352 Bergström, S.M., Eriksson, M.E., Young, S. a., Ahlberg, P., and Schmitz, B. 2014. Hirnantian

353 (latest Ordovician) $\delta^{13} \mathrm{C}$ chemostratigraphy in southern Sweden and globally: a refined

354 integration with the graptolite and conodont zone successions. GFF, 136(2): 355-386.

$355 \quad$ doi:10.1080/11035897.2013.851734.

356 Bergström, S.M., Saltzman, M.R., Leslie, S.A., Ferretti, A., and Young, S.A. 2015. Trans-

357 Atlantic application of the Baltic Middle and Upper Ordovician carbon isotope zonation.

358 Estonian Journal of Earth Sciences, 64(1): 8-12. doi:10.3176/earth.2015.02.

359 Bertrand, R., and Héroux, Y. 1987. Chitinozoan, graptolite, and scolecodont reflectance as an

360 alternative to vitrinite and pyrobitumen reflectance in Ordovician and Silurian strata,

361 Anticosti Island, Quebec, Canada. AAPG Bulletin, 71: 951-957.

362 Bordet, E., Malo, M., and Kirkwood, D. 2010. A structural study of western Anticosti Island, St.

363 Lawrence platform, Quebec: a fracture analysis that integrates surface and subsurface 
structural data. Bulletin of Canadian Petroleum Geology, 58(1): 36-55.

365 Copper, P. 2001. Reefs during the multiple crises towards the Ordovician-Silurian boundary:

366 Anticosti Island, eastern Canada, and worldwide. Canadian Journal of Earth Sciences, 38:

$367 \quad 153-171$.

368 Copper, P., and Jin, J. 2014. The revised Lower Silurian (Rhuddanian) Becscie Formation,

369 Anticosti Island, eastern Canada records the tropical marine faunal recovery from the end-

370 Ordovician Mass Extinction. Newsletters on Stratigraphy, 47(1): 61-83. doi:10.1127/0078-

$371 \quad 0421 / 2014 / 0040$.

372 Copper, P., Jin, J., and Desrochers, A. 2013. The Ordovician-Silurian boundary (late Katian-

373 Hirnantian) of western Anticosti Island: revised stratigraphy and benthic megafaunal

$374 \quad$ correlations. Stratigraphy, 10(4): 213-227.

375 Courtinat, B., and Racheboeuf, P.R. 1997. Mochtyellidés versus Tétraprionidés? Un question

376 posée par des scolécodontes ordoviciens de l'île d'Anticosti (Quebec). Geobios, 20: 149_ $377 \quad 159$.

378 Delabroye, A., and Vecoli, M. 2010. The end-Ordovician glaciation and the Hirnantian Stage: A 379 global review and questions about Late Ordovician event stratigraphy. Earth-Science

$380 \quad$ Reviews, 98(3-4): 269-282. doi:10.1016/j.earscirev.2009.10.010.

381 Delabroye, A., Munnecke, A., Vecoli, M., Copper, P., Tribovillard, N., Joachimski, M.M.,

382 Desrochers, A., and Servais, T. 2011a. Phytoplankton dynamics across the

383 Ordovician/Silurian boundary at low palaeolatitudes: Correlations with carbon isotopic and

384 glacial events. Palaeogeography, Palaeoclimatology, Palaeoecology, 312(1-2): 79-97.

385 doi:10.1016/j.palaeo.2011.09.011. 
386 Delabroye, A., Vecoli, M., Hints, O., and Servais, T. 2011b. Acritarchs from the Ordovician-

387 Silurian boundary beds of the Valga-10 drill core, southern Estonia (Baltica) and their

388 stratigraphical and palaeobiogeographical implications. Palynology, 35(1): 4-45.

389 doi:10.1080/01916122.2010.491639.

390 Desrochers, A., Farley, C., Achab, A., Asselin, E., and Riva, J.F. 2010. A far-field record of the end Ordovician glaciation: The Ellis Bay Formation, Anticosti Island, Eastern Canada. Palaeogeography, Palaeoclimatology, Palaeoecology, 296(3-4): 248-263. doi:10.1016/j.palaeo.2010.02.017.

394 Eriksson, M., and Bergman, C.F. 1998. Scolecodont systematics exemplified by the polychaete Hadoprion cervicornis (Hinde, 1879). Journal of Paleontology, 72(3): 477-485.

396 Eriksson, M., and Bergman, C.F. 2003. Late Ordovician jawed polychaete faunas of the type Cincinnatian region, U.S.A. Journal of Paleontology, 77(3): 509-523.

398 Eriksson, M.E., and Frisk, Å.M. 2011. Polychaete palaeoecology in an early Late Ordovician marine astrobleme of Sweden. Geological Magazine, 148(2): 269-287. doi:http://dx.doi.org/10.1017/S0016756810000579.

401 Eriksson, M.E., and Hints, O. 2009. Vagrant benthos (Annelida; Polychaeta) associated with 402 Upper Ordovician carbonate mud-mounds of subsurface Gotland, Sweden. Geological 403 Magazine, 146(3): 451-462. doi:10.1017/S0016756809005962.

404 Eriksson, M., Jeppsson, L., Bergman, C.F., and Hints, O. 2000. Paranomenclature and the rules 405 of Zoological Nomenclature - with examples from fossil polychaete jaws (scolecodonts). Micropaleontology, 46(2): 186-188.

Eriksson, M.E., Leslie, S.A., and Bergman, C.F. 2005. Jawed polychaetes from the upper Sylvan 
409 Eriksson, M.E., Hints, O., Paxton, H., and Tonarova, P. 2013. Chapter 18 Ordovician and 410 Silurian polychaete diversity and biogeography. Geological Society, London, Memoirs, $411 \quad 38(1): 265-272$. doi:10.1144/M38.18.

412 Ghienne, J.-F., Desrochers, A., Vandenbroucke, T.R.A., Achab, A., Asselin, E., Dabard, M.-P., 413 Farley, C., Loi, A., Paris, F., Wickson, S., and Veizer, J. 2014. A Cenozoic-style scenario 414 for the end-Ordovician glaciation. Nature Communications, 5: 4485. doi:10.1038/ncomms5485.

Hinde, G.J. 1879. On annelid jaws from the Cambro-Silurian, Silurian and Devonian formations in Canada and from the Lower Carboniferous in Scotland. Quarterly Journal of the

Hints, L., Hints, O., Kaljo, D., Kiipli, T., Männik, P., Nõlvak, J., and Pärnaste, H. 2010. Hirnantian (latest Ordovician) bio- and chemostratigraphy of the Stirnas-18 core, western Latvia. Estonian Journal of Earth Sciences, 59(1): 1-24. doi:10.3176/earth.2010.1.01.

Hints, O. 1998. Late Viruan (Caradoc) polychaete jaws from North Estonia and the St. Petersburg 423 region. Acta Palaeontologica Polonica, 43: 471-516.

Hints, O. 1999. Two new polychaete families from the Upper Ordovician of Estonia. Palaeontology, 42(5): 897-906.

Hints, O. 2000. Ordovician eunicid polychaetes of Estonia and surrounding areas: review of their distribution and diversification. Review of Palaeobotany and Palynology, 113(1-3): 41-55.

428 Hints, O. 2001. Distribution of scolecodonts. In Valga (10) drill core. Estonian Geological 
14.

431 Hints, O., and Eriksson, M.E. 2007. Diversification and biogeography of scolecodont-bearing polychaetes in the Ordovician. Palaeogeography, Palaeoclimatology, Palaeoecology, 245(1-

Hints, O., and Eriksson, M.E. 2010. Ordovician Polychaeturid Polychaetes: Taxonomy, 2): 95-114. doi:10.1016/j.palaeo.2006.02.029.

Hints, O., Paris, F., and Al-Hajri, S. 2015. Late Ordovician scolecodonts from the Qusaiba-1 core Distribution and Palaeoecology. Acta Palaeontologica Polonica, 55(2): 309-320. doi:10.4202/app.2009.0086. hole, central Saudi Arabia, and their paleogeographical affinities. Review of Palaeobotany and Palynology, 212: 85-96. doi:10.1016/j.revpalbo.2014.08.013.

Jones, D.S., Fike, D.A., Finnegan, S., Fischer, W.W., Schrag, D.P., and McCay, D. 2011. Terminal Ordovician carbon isotope stratigraphy and glacioeustatic sea-level change across Anticosti Island (Quebec, Canada). Geological Society of America Bulletin, 123(7-8): 1645-1664. doi:10.1130/B30323.1.

Kaljo, D., Hints, L., Männik, P., and Nõlvak, J. 2008. The succession of Hirnantian events based

Kielan-Jaworowska, Z. 1966. Polychaete jaw apparatuses from the Ordovician and Silurian of on data from Baltica: brachiopods, chitinozoans, conodonts, and carbon isotopes. Estonian 
doi:10.1130/B30812.1.

453

454

455

456

457

458

Petryk, A.A. 1987. The Ordovician-Silurian boundary succession at Cap Henri, Anticosti Island, Quebec. Northeastern Section of the Geological Society of America, 5: 373-377.

Rubel, M., Hints, O., Männik, P., Meidla, T., Nestor, V., Sarv, L., and Sibul, I. 2007. Lower Silurian biostratigraphy of the Viirelaid core, western Estonia. Estonian Journal of Earth Sciences, 56(4): 193-204. doi:10.3176/earth.2007.01.

Sami, T., and Desrochers, A. 1992. Episodic sedimentation on an early Silurian, storm-dominated carbonate ramp, Becscie and Merrimack formations, Anticosti Island, Canada. Sedimentology, 39: 355-381.

Schuchert, C., and Twenhofel, W.H. 1910. Ordovician-Silurian section of the Mingan and Anticosti islands, Gulf of Saint Lawrence. Geological Society of America Bulletin, 21: 677716.

Szaniawski, H. 1970. Jaw apparatuses of the Ordovician and Silurian polychaetes from the Mielnik borehole. Acta Palaeontologica Polonica, 15: 445-472.

Szaniawski, H., and Drygant, D. 2014. Lochkovian, early Devonian scolecodonts from Podolia, Ukraine. Acta Palaeontologica Polonica, 59(4): 967-983. doi:10.4202/app.2012.0120.

Tonarová, P., Eriksson, M.E., and Hints, O. 2012. A jawed polychaete fauna from the late Ludlow Kozlowskii event interval in the Prague Basin (Czech Republic). Bulletin of Geosciences, 87: 713-732. doi:10.3140/bull.geosci.1317.

Tonarová, P., Hints, O., and Eriksson, M.E. 2014. Impact of the Silurian Ireviken Event on polychaete faunas: new insights from the Viki drill core, western Estonia. GFF, 136(1): 270-274. doi:10.1080/11035897.2013.862855. 
474 Torsvik, T.H., and Cocks, L.R.M. 2013. Chapter 2 New global palaeogeographical

475 reconstructions for the Early Palaeozoic and their generation. Geological Society, London, $476 \quad$ Memoirs, 38(1): 5-24. doi:10.1144/M38.2.

477 Twenhofel, W.H. 1928. Geology of Anticosti Island: Canada. Geological Survey Memoir, 154: $478 \quad 1-481$.

479 Vecoli, M., Delabroye, A., Spina, A., and Hints, O. 2011. Cryptospore assemblages from Upper 480 Ordovician (Katian-Hirnantian) strata of Anticosti Island, Québec, Canada, and Estonia:

481 Palaeophytogeographic and palaeoclimatic implications. Review of Palaeobotany and 482 Palynology, 166(1-2): 76-93. doi:10.1016/j.revpalbo.2011.05.006.

483 Whittle, R., Gabbott, S., Aldridge, R., and Theron, J. 2008. Late Ordovician (Hirnantian)

484 scolecodont clusters from the Soom Shale Lagerstatte, South Africa. Journal of 485 Micropalaeontology, 27(2): 147-159. doi:10.1144/jm.27.2.147. 
Figure captions

489 Figure 1. Locality map showing the study area and distribution of the Vauréal, Ellis Bay and 490 Becscie formations.

Figure 2. Stratigraphic background, sample positions and ranges of scolecodonts. Size of the circles denotes relative abundance. Note that some samples were too small to provide reliable taxon counts (member names in accordance with Copper et al. 2013).

Figure 3. SEM photos of selected scolecodonts. Scale bars $0.1 \mathrm{~mm}$. C, F, M-N, P, R-W, Y and AE from the Vauréal Formation, all others from the Ellis Bay Formation. A, Tetraprion cf. pozaryskae, right MI, GIT 714-1, sample 410; B, Tetraprionidae gen. et sp. nov., right MI, GIT 714-2, sample 410; C, Mochtyella cf. trapezoidea, left MI, GIT 714-3, sample 246; D,

500 Mochtyella cf. duplicidentata, right MI, GIT 714-4, sample 410; E, Vistulella cf. kozlowskii, right 501 MIa, GIT 714-5, sample 410; F, Vistulella cf. kozlowskii, left MI, GIT 714-6, sample 246; G, 502 Pistoprion transitans, left MI, GIT 714-7, sample 410; H, Pistoprion transitans, right MII, GIT 503 714-8, sample 410; I, Xanioprion sp. A, left MII, GIT 714-9, sample 410; J, Xanioprion sp. A, 504 right MI, GIT 714-10, sample 410; K, Oenonites aff. wyszogrodensis, left MI, GIT 714-11, 505 sample 318; L, Oenonites aff. wyszogrodensis, right MI, GIT 714-12, sample 318; M, Oenonites 506 aff. latus, right MI with fused basal plate and additional teeth, GIT 714-13, sample 268; N, 507 Oenonites aff. latus, right MI, GIT 714-14, sample 268; O, Oenonites sp., right MI, GIT 714-15, 508 sample 410; P, Oenonites cf. marlenediesae, right MI, GIT 714-16, sample 268; Q, Oenonites aff. 509 wyszogrodensis, basal plate, GIT 714-17, sample 410; R, Pteropelta gladiata, left MI, GIT 714- 
510 18, sample 268; S, Pteropelta gladiata, left MI, GIT 714-19, sample 268; T, Pteropelta gladiata,

511 right MI, GIT 714-20, sample 268; U, Pteropelta gladiata, right MI, GIT 714-21, sample 268; V,

512 Ramphoprion cf. ineptus, basal plate, GIT 714-22, sample 268; W, Ramphoprion cf. ineptus,

513 right MI, GIT 714-23, sample 268; X, Ramphoprion sp., left MII, GIT 714-24, sample 410; Y,

514 Ramphoprion cf. ineptus, left MI, GIT 714-25, sample 268; Z, Kettnerites sp. A, left MI, GIT

515 714-26, sample 318; AA, Kettnerites sp. A, left MII, GIT 714-27, sample 318; AB, Kettnerites

516 sp. A, right MII, GIT 714-28, sample 318; AC, Kettnerites sp. A, right MII, GIT 714-29, sample

517 318; AD, Kettnerites sp. A, right MI, GIT 714-30, sample 318; AE, Kalloprion sp., right MI, GIT

518 714-31, sample 268; AF, Atraktoprion sp., right MI, GIT 714-32, sample 318; AG, Atraktoprion

519 sp., left MI, GIT 714-33, sample 318; AH, Hadoprion cervicornis, left MI, GIT 714-34, sample

520 318; AI, Hadoprion cervicornis, right MI, GIT 714-35, sample 318.

522 Figure 4. Pie-charts showing family-level composition of latest Ordovician polychaete faunas

523 from Anticosti Island, and comparison with type Cincinnatian area and Baltoscandia

524 assemblages. Type Cincinnatian area data are after Hints and Eriksson (2007), Orjaku core data

525 showing lumped counts from two samples from the Adila Formation, Pirgu Regional Stage;

526 Stirnas core data after Hints et al. (2010) lumping counts from 38 samples from the Kuldiga

527 Formation, Porkuni Regional Stage. Placognatha division also includes tetraprionids with

528 ctenognath apparatus architecture. Note that individual samples from all regions and intervals

529 may show different patterns. 


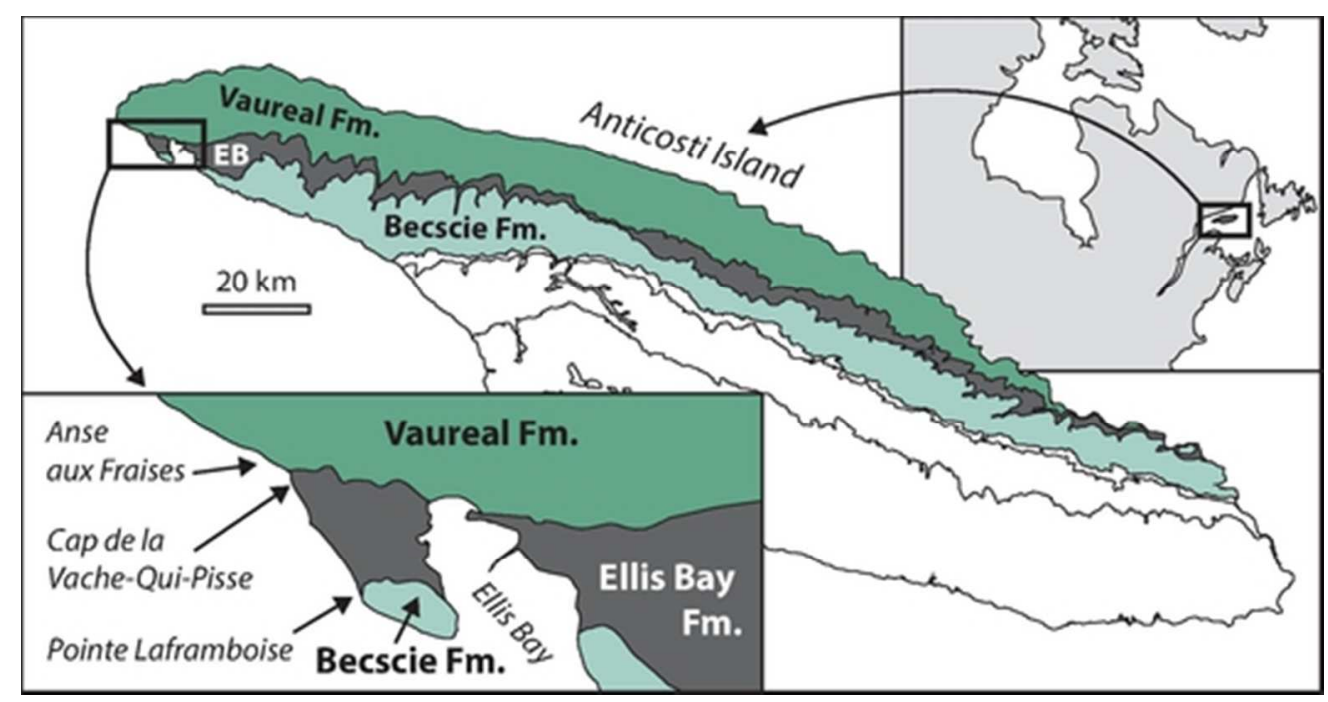

Figure 1. Locality map showing the study area and distribution of the Vauréal, Ellis Bay and Becscie formations.

$44 \times 23 \mathrm{~mm}(300 \times 300 \mathrm{DPI})$ 


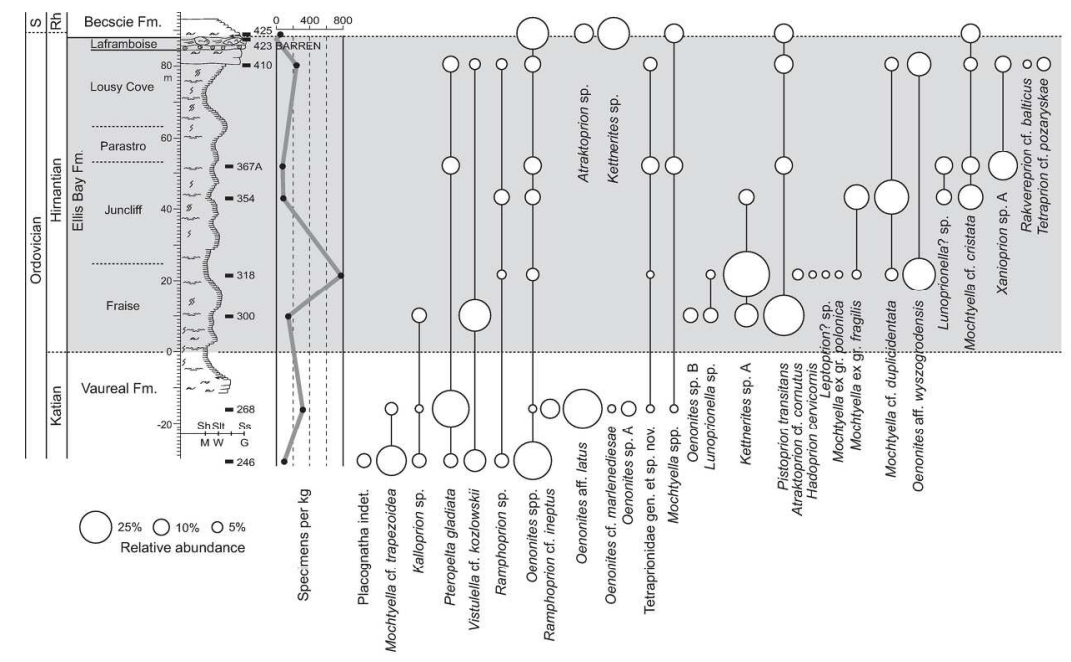

Figure 2. Stratigraphic background, sample positions and ranges of scolecodonts. Size of the circles denotes relative abundance. Note that some samples were too small to provide reliable taxon counts (member names in accordance with Copper et al. 2013). $194 \times 166 \mathrm{~mm}(300 \times 300 \mathrm{DPI})$ 


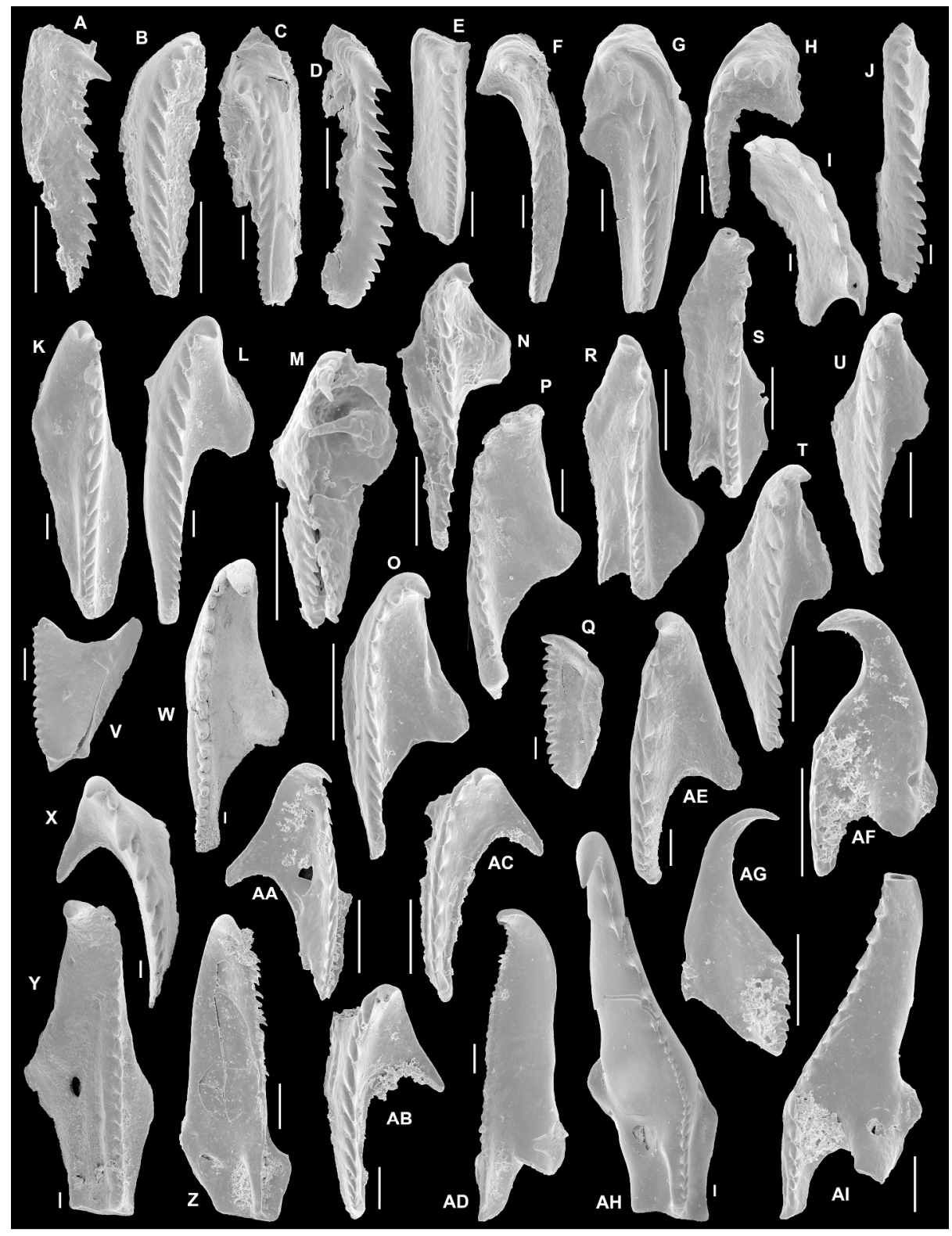

Figure 3. SEM photos of selected scolecodonts. Scale bars $0.1 \mathrm{~mm}$. C, F, M-N, P, R-W, Y and AE from the Vauréal Formation, all others from the Ellis Bay Formation. A, Tetraprioncf. pozaryskae, right MI, GIT 714-1, sample 410; B, Tetraprionidae gen. et sp. nov., right MI, GIT 714-2, sample 410; C, Mochtyella cf. trapezoidea, left MI, GIT 714-3, sample 246; D, Mochtyella cf. duplicidentata, right MI, GIT 714-4, sample 410; E, Vistulella cf. kozlowskii, right MIa, GIT 714-5, sample 410; F, Vistulella cf. kozlowskii, left MI, GIT 714-6, sample 246; G, Pistoprion transitans, left MI, GIT 714-7, sample 410; H, Pistoprion transitans, right MII, GIT 714-8, sample 410; I, Xanioprion sp. A, left MII, GIT 714-9, sample 410; J, Xanioprion sp. A, right

MI, GIT 714-10, sample 410; K, Oenonites aff. wyszogrodensis, left MI, GIT 714-11, sample 318; L, Oenonites aff. wyszogrodensis, right MI, GIT 714-12, sample 318; M, Oenonites aff. latus, right MI with fused basal plate and additional teeth, GIT 714-13, sample 268; N, Oenonites aff. latus, right MI, GIT 71414, sample 268; O, Oenonites sp., right MI, GIT 714-15, sample 410; P, Oenonites cf. marlenediesae, right MI, GIT 714-16, sample 268; Q, Oenonites aff. wyszogrodensis, basal plate, GIT 714-17, sample 410; R, Pteropelta gladiata, left MI, GIT 714-18, sample 268; S, Pteropelta gladiata, left MI, GIT 714-19, sample 
268; T, Pteropelta gladiata, right MI, GIT 714-20, sample 268; U, Pteropelta gladiata, right MI, GIT 714-21, sample 268; V, Ramphoprion cf. ineptus, basal plate, GIT 714-22, sample 268; W, Ramphoprion cf. ineptus, right MI, GIT 714-23, sample 268; X, Ramphoprion sp., left MII, GIT 714-24, sample 410; Y, Ramphoprion cf. ineptus, left MI, GIT 714-25, sample 268; Z, Kettnerites sp. A, left MI, GIT 714-26, sample 318; AA, Kettnerites sp. A, left MII, GIT 714-27, sample 318; AB, Kettnerites sp. A, right MII, GIT 714-28, sample 318; AC, Kettnerites sp. A, right MII, GIT 714-29, sample 318; AD, Kettnerites sp. A, right MI, GIT 714-30, sample 318; AE, Kalloprion sp., right MI, GIT 714-31, sample 268; AF, Atraktoprion sp., right MI, GIT 71432, sample 318; AG, Atraktoprion sp., left MI, GIT 714-33, sample 318; AH, Hadoprion cervicornis, left MI, GIT 714-34, sample 318; AI, Hadoprion cervicornis, right MI, GIT 714-35, sample 318. $236 \times 308 \mathrm{~mm}(300 \times 300 \mathrm{DPI})$ 


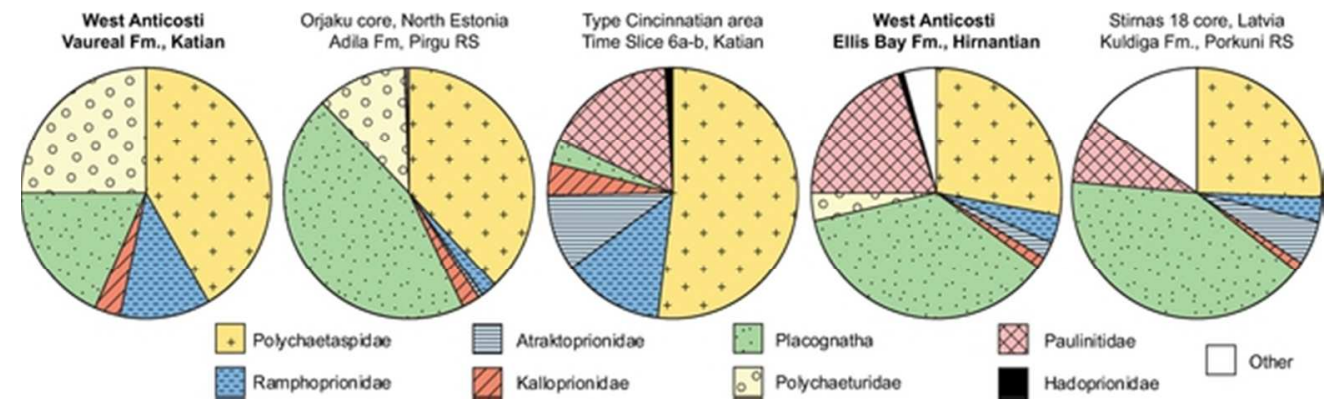

Figure 4. Pie-charts showing family-level composition of latest Ordovician polychaete faunas from Anticosti Island, and comparison with type Cincinnatian area and Baltoscandia assemblages. Type Cincinnatian area data are after Hints and Eriksson (2007), Orjaku core data showing lumped counts from two samples from the Adila Formation, Pirgu Regional Stage; Stirnas core data after Hints et al. (2010) lumping counts from

38 samples from the Kuldiga Formation, Porkuni Regional Stage. Placognatha division also includes tetraprionids with ctenognath apparatus architecture. Note that individual samples from all regions and intervals may show different patterns. $53 \times 15 \mathrm{~mm}(300 \times 300$ DPI $)$ 